LOKABASA
Jurnal Kajian Bahasa, Sastra, dan Budaya Daerah serta Pengajarannya
Volume 10, No. 2, Bulan Oktober Tahun 2019, Hal. 214-225

\title{
Model Brain Writing dalam Meningkatkan Kemampuan Menulis Wawangsalan
}

\author{
Sumartini ${ }^{1}$, Hernawan ${ }^{2}$ \\ ${ }^{1}$ SD Sundawenang-Tasikmalaya, ${ }^{2}$ Universitas Pendidikan Indonesia \\ sumartini256@gmail.com
}

\begin{abstract}
Sejarah Artikel: Diterima (13 Juli 2019); Diperbaiki (12 Agustus 2019); Disetujui (5 Oktober 2019); Pusblished (31 Oktober 2019)

Bagaimana mengutip artikel ini (dalam gaya APA): Sumartini, Hernawan. (2019) Model Brain Writing dalam Meningkatkan Kemampuan Menulis Wawangsalan. Lokabasa 10(2). 214-225 doi: $\underline{10.17509 / j l b . v 10 i 2.21364}$
\end{abstract}

Abstrak: Penelitian ini dilatarbelakangi oleh kurangnya kemampuan siswa dalam menulis wawangsalan. Tujuan dari penelitian ini adalah untuk mendeskripsikan kemampuan menulis wawangsalan sebelum dan sesudah menggunakan model brain writing, meningkat, serta mendeskripsikan perbedaan antara kemampuan menulis wawangsalan sebelum dan sesudah menggunakan model brain writing. Metode yang digunakan dalam penelitian ini adalah metode kuasi eksperimen, dengan menggunakan desain one group pretest and posttest ke 30 siswa di kelas VIII-G SMP Pasundan 4 Bandung Tahun Ajaran 2018/2019. Teknik yang digunakan yaitu tehnik tes, sedangkan instrumennya berupa tes menulis wawangsalan. Hasil penelitian ini adalah (1) kemampuan menulis wawangsalan siswa kelas VIII-G SMP Pasundan 4 Bandung sebelum menggunakan model pangajaran brain writing rata-rata memperoleh nilai 43,2; (2) kemampuan menulis wawangsalan sesudah menggunakan model pembelajaran Brain Writing rata-rata memperoleh nilai 76; (3) ada peningkatan kemampuan menulis wawangsalan sesudah menggunakan model brain writing yaitu dari 43,2 menjadi 76, utamanya dalam aspek hubungan isi dan judul wangsal; (4) ada perbedaan antara kemampuan menulis wawangsalan sebelum dan sesudah menggunakan model pembelajaran brain writing. Berdasarkan hasil uji statistik nilai signifikansi (Sig.2-tailed) yaitu $(0,000<0,05)$ atau kurang dari 0,05 . Dengan demikian, H1 ditarima serta H0 ditolak. Artinya, ada perbedaan yang signifikan antara kemampuan menulis wawangsalan sebelum dan sesudah menggunakan model brain writing. Hal ini menunjukkan bahwa model pembelajaran brain writing dapat meningkatkan kemampuan menulis wawangsalan siswa kelas VIII-G SMP Pasundan 4 Bandung Tahun Ajaran 2018/2019.

Kata Kunci: image streaming; metode pembelajaran; menulis sajak

\section{Brain Writing Model in Improving The Ability of Writing Wawangsalan}

Abstract: This research is motivated by the lack of ability of students in writing wawangsalan. The purpose of this study is to describe the ability to write wawangsalan students of class VIII-G SMP Pasundan 4 Bandung before and after using the model of learning brain writing, increase or not after using the models of learning brain writing, and the differences using the model of learning brain writing. The method used in this research is quasi-experimental method, using one group pretest and posttest design. Sources of data in this study were 30 students of class VIII-G SMP Pasundan 4 Bandung Academic Year 2018/2019. Techniques used are test techniques, while the instrument is a writing test wawangsalan. The results of this study are (1) the ability to write students wawangsalan VIII-G SMP Pasundan 4 Bandung before using the model make-up brain writing up the value of 43,2; (2) the ability to write wawangsalan after using the brain writing learning model on average to get the value of 76;

Copyright (C2019 Universitas Pendidikan Indonesia. All rights reserved. 
(3) there is an increase in the ability to write wawangsalan after using brain writing model, from 34,2 to 76, mainly in aspects of the content and title relationship wangsal, and (4) there is a difference between the writing ability of wawangsalan before and after using the brain writing model. Based on statistical tests of significance values (Sig-2 tailed), namely $(0,000<0,05)$ or less than 0,05. Which means that the alternative hypothesis $(\mathrm{Ha})$ is accepted and the null hypothesis $(\mathrm{Ho})$ is rejected. This shows that the model of brain writing learning can improve students' writing ability of grade VIII-G SMP Pasundan 4 Bandung Academic Year 2018/2019.

Keywords: brain writing learning model; write wawangsalan

\section{PENDAHULUAN}

Pada hakikatnya manusia mempunyai kemampuan untuk berkomunikasi. Kemampuan berkomunikasi disebut juga dengan kemampuan menggunakan bahasa. Kemampuan berkomunikasi berdasarkan tingkat kemampuan menguasai bahasa terdiri atas: (1) menyimak, (2) berbicara, (3) membaca, dan (4) menulis. Seseorang dianggap memiliki keterampilan berbahasa jika terampil menyimak, berbicara, membaca, dan menulis,. Menyimak dan membaca bersifat reseptif, sedangkan berbicara dan menulis sifatnya produktif.

Darmadi dalam Aljatila (2015) mengemukakan bahwa menulis sangat penting untuk kehidupan sehari-hari. Fungsinya tiada lain agar dapat melakukan komunikasi, menyampaikan gagasan, dan hubungan sosial dengan orang lain. Terlebih lagi di lingkungan pendidikan, menulis merupakan keterampilan yang harus dikuasai oleh siswa. Jika siswa telah meguasai keterampilan menulis, tentu saja akan memudahkan siswa dalam menguasai keterampilan yang lainnya. Bahkan Suherman (2019, hlm. 264) menegaskan bahwa menulis merupakan literasi dasar yang harus dikuasai oleh siswa selain enam jenis literasi dasar lainnya yaitu literasi numerasi, literasi sains, literasi finansial, literasi digital, serta literasi budaya dan kewargaan.
Bahwa menulis itu penting baik di tingkat satuan pendidikan maupun di masyarakat luas, hal tersebut telah dirumuskan oleh perancang kurikulum dalam Kompetensi Inti dan Kompetensi Dasar (KIKD), sehingga menjadi acuan dalam proses pembelajaran.

Kenyataan yang terjadi di lapagan setelah diobservasi, ternyata keterampilan menulis siswa SMP masih sangat kurang, terutama dalam menulis wawangsalan.

Kegiatan menulis wawangsalan merupakan kegiatan yang harus diajarkan di SMP sebab ada dalam Kompetensi Inti Kompetensi Dasar (KIKD) 8.4.4 Mengekspresikan sisindiran dalam bentuk tulisan dan lisan (misalnya melalui poster, meme, atau tempas sindir) dengan memperhatikan struktur, ekspresi, dan lentong kalimat secara lisan dan tulisan (Dinas Pendidikan Jawa Barat, 2013, hlm. 47).

Kompetensi yang ingin dicapai dalam pembelajaran menulis wawangslaan yaitu struktur yang terdiri atas sampiran (cangkang) dan isi (eusi), jumlah suku kata tiap baris (guru wilangan) yang dibentuk oleh delapan suku kata, serta kaidah bahasa yang terdiri atas ejaan, serta diksi yang sesuai dengan aturan menulis wawangsalan.

Kenyataan di sekolah, berdasarkan hasil wawancara dengan guru bahasa Sunda SMP Pasundan 4 Bandung, Asep Ruhimat, bahwa keterampilan menulis wawangsalan 
dianggap susah, terutama dalam struktur dan aspek kebahasaan. Faktor penyebabnya yaitu dalam mencari ide atau kata, dan isi wangsalnya. Selain itu, siswa menghadapi beberapa persoalan dalam menentukan guru wilangan yang lebih atau kurang dari jumlah suku kata yang sudah ditentukan. Faktor lainnya yaitu dalam ejaan, membedakan huruf vokal é, eu, dan e, menggunakan koma (,) dan titik (.) diakhir baris, serta memilih diksi yang sesuai dengan isi wangsalnya.

Disamping itu, kurangnya kemampuan menulis wawangsalan di sekolah diakibatkan oleh pembelajaran menulis wawangsalan itu sendiri yang dianggap tidak menarik dan kurang bervariasi dalam mengajarkannya. Oleh sebab itu, perlu diterapkan model pembelajaran yang kreatif untuk mengatasai permasalahan tersebut.

Model pembelajaran merupakan landasan praktek pembelajaran hasil diturunkannya teori psikologi pendidikan dan teori belajar yang dirancang berdasarkan analisis mengenai implementasi kurikulum (Nasution, 2017).

Model pembelajaran yang dianggap bisa mengatasi masalah itu adalah model brain writing, sebab model tersebut dianggap dapat meningkatkan keterampilan menulis, bisa mendukung siswa dalam mengembangkan ide atau topik dalam bentuk teks pendek. Model ini bisa mendukung siswa yang diam atau kurang percaya diri menjadi siswa yang berani menyampaikan ide-idenya terutama dalam bentuk tulisan.

Dengan menggunakan model brain writing, siswa bisa memberi pendapat dalam bentuk tulisan dan merespon ide-ide dari siswa lain dalam satu kelompok. Brain writing menurut Michalko (2004, hlm. 315) merupakan satu pendekatan gagasan, ketika satu kelompok menghasilkan ide-ide secara tertulis.

Model pembelajaran brain writing merupakan satu model pembelajaran yang dalam penyampaiannya melalui bentuk tulisan. Secara leksikografi, brain artinya otak, write artinya menulis. Jadi, brain writing yaitu menulis segala hal yang ada dalam otak. Brain writing merupakan cara yang bisa mengatasi setiap orang untuk menuangkan ide atau gagasan melalui tulisan.

Selain secara teoritis, alasan memilih brain writing juga secara empiris tekah ada yang meneliti dan dianggap berhasil, di antaranya dilakukan oleh Nurmayani (2015) yang berjudul "Keefektifan Strategi Brain Writing dalam Pembelajaran Menulis Cerpen pada Siswa Kelas X SMA Negeri 1 Ngaglik)". Penelitian Azizah (2015) yang berjudul "Keefektifan Model Brain Writing dalam Pembelajaran Memproduksi Teks Eksplanasi pada Siswa Kelas VII SMP Negeri 1 Sewon Bantul DIY)".

Hasil dari penelitian ini menjelaskan bahwa model pembelajaran brain writing efektif dalam pembelajaran menulis, yaitu menulis cerpen dan menulis teks eksplanasi. Persamaan penelitian tersebut dengan penelitian ini yaitu dalam penggunaan modelnya (brain writing), tetapi berbeda dalam materi ajar yang dipraktekannya, yang terdahulu dalam cerpen dan teks eksplanasi sedangkan yang sekarang dalam wawangsalan.

Berdasarkan pertimbangan di atas, bisa disimpulkan bahwa model brain writing merupakan model pembelajaran yang bisa mengatasi masalah dalam menulis wawangsalan. Model brain writing bisa digunakan sebagai model pembelajaran yang lebih kreatif dan inovatif, serta 
menciptakan suasana belajar yang disukai oleh siswa.

\section{METODE}

Metode yang digunakan dalam penelitian ini adalah metode kuantitatif melalui pendekatan kuasi eksperimen disebut juga eksperimen semu, yaitu satu penelitian yang menggunakan kelas eksperimen serta tidak menggunakan kelas control Nazir (2014, hlm. 73). Menurut Arikunto (2013, hlm. 123) metode kuasi eksperimen dibagi menjadi tiga jenis, yaitu 1) one shot case study, 2) pretest and posttest, 3) static group comparison.

Desain yang digunakan dalam penelitian ini yaitu pretest dan posttest. Penelitian ini dilaksanakan dengan cara terlebih dahulu memberi pretest untuk mengukur kemampuan awal siswa dalam pembelajaran menulis wawangsalan. Sesudah itu, siswa diberi treatment untuk melatih kemampuan siswa dalam menulis wawangsalan melalui model pembelajaran brain writing, lalu siswa diberi posttest untuk mengukur kemampuan akhir dalam pembelajaran menulis wawangsalan.

Adapun desain penelitian ini digambarkan seperti di bawah.

\begin{tabular}{lll}
\multicolumn{3}{c}{ Tabél 1 } \\
\multicolumn{3}{c}{ Desain Panalungtikan } \\
\begin{tabular}{lll}
\hline Pretest & Treatment & Posttest \\
\hline $\mathbf{O}_{1}$ & $\mathrm{X}$ & $\mathrm{O}_{2}$ \\
\hline \multicolumn{4}{c}{ Sugiyono $(2012, \mathrm{hlm}}$. \\
\end{tabular}
\end{tabular}

Sumber data dalam penelitian ini yaitu siswa kelas VIII-G SMP Paundan 4 Bandung tahun ajaran 2018/2019 yang jumlahnya 30 siswa, terdiri atas 15 perempuan dan 15 laki-laki. Teknik yang digunakan untuk mengumpulkan data yaitu teknik tes. Teknik tes digunakan untuk mengumpulkan data karangan kemampuan menulis wawangsalan sebelum dan sesudah menggunakan model brain writing.

Teknik tes digunakan untuk mengumpulkan data kemampuan menulis wawangsalan siswa yang terdiri atas ejaan, diksi, guru wilangan (jumlah suku kata tiap baris), kerapihan tulisan, ketepatan tulisan dan ketepatan pengarang dalam hubungan isi yang sesuai dengan tema wawangsalan. Tes tulis digunakan untuk mengukur kemampuan siswa kelas VIII-G dalam menulis wawangsalan. Untuk mengolah data yang sudah terkumpul, dilakukan uji sipat data, yang terdiri atas uji normalitas dan uji hipotesis. Uji normalitas digunakan untuk menentukan distribusi normal atau tidaknya data (Sudajana, 2005). Dikemukakan Sujarweni (2007, hlm. 55) bahwa uji normalitas mempunyai tujuan untuk mengetahui distribusi data dalam variabel yang digunakan dalam penelitian. Data yang layak digunakan yaitu mempunyai distribusi normal. Uji hipotesis menurut Mustaqim (2017, hlm. 38) digunkan untuk mengetahui diterima atau tidaknya hipotesis dalam penelitian.

Berdasarkan tekniknya, penelitian ini melakukan observasi langsung pada objek yang diteliti. Dalam penelitian ini dilakukan dua kali tes, yaitu sebelum dan sesudah menggunakan model brain writing.

\section{HASIL DAN PEMBAHASAN}

Berdasarkan hasil penelitian yang dilaksanakan di SMP Pasundan 4 Bandung, ditemukan data hasil sebelum dan sesudah menggunakan model brain writing.

Penelitian ini dilakukan untuk mengetahui kemampuan menulis wawangsalan sebelum dan sesudah menggunakan model brain writing, meningkat atau tidaknyakemampuan menulis wawangsalan 
sesudah menggunakan model brain writing, serta membuktikan ada perbedaan yang signifikan antara kemampuan menulis wawangsalan sebelum dan sesudah menggunakan model brain writing.

Supaya lebih jelas, hasil kemampuan siswa dalam menulis wawangsalan sebelum dan sesudah menggunakan model brain writing di SMP Pasundan 4 Bandung tahun ajaran 2018/2019, seperti di bawah ini.

\section{Kemampuan Menulis Wawangsalan sebelum Menggunakan Model Brain Writing}

Dalam menulis wawangsalan, siswa disarankan untuk mempunyai keterampilan menulis wawangsalan, supaya aspek-aspek yang dinilai dalam menulis wawangsalan lebih baik. Kemampuan menulis wawangsalan dilihat dari lima aspek, yaitu: 1) aspek ejaan, dalam menentukan huruf diawal kalimat, aturan dalam menulis wawangsalan, kata yang digunakan harus mengandung arti, 3) aspek guru wilangan, (jumlah suku kata) harus memenuhi delapan suku kata, 4) aspek kerapihan tulisan, kejelasan tulisan dan hurufnya, serta 5) hubungan isi dan judul wangsal, sesuai atau tidaknya antar larik dalam membuat wawangsalan (Windyagiri, 2011, hlm. 12).

Siswa yang sudah memenuhi aspek dalam menulis wawangsalan, dianggap bahwa siswa tersebut sudah mampu, sedangkan siswa yang belum memenuhiaspek-aspek dalam menulis wawangsalan dianggap belum mampu.

Siswa yang belum mampu dalam menulis wawangsalan, guru bisa menerapkan model brain writing, untuk mengatasi masalah itu.

Model brain writing bisa mendorong siswa dalam mengembangkan ide atau gagasan ke dalam bentuk tulisan, menghindari konflik, serta mendorong siswa yang diam menjadi aktif.Michalko (2004, hlm. 315) mengemukakan bahwa model brain writing merupakan satu pendekatan gagasan ketika satu kelompok menghasilkan ide-ide secara tertulis.

Kemampuan menulis wawangsalan siswa sebelum menggunakan model brain writing, semua siswa yang jumlahnya 30 siswa atau $100 \%$ termasuk kategori belum mampu, artinya siswa masih belum mampu dalam mencapai skor maksimal dari semua aspek yang telah ditentukan dalam menulis wawangsalan (Hartfield, spk, 1985, hlm. 91 dan Nurgiyantoro, 1988, hlm. 305-306 dalam Kuswari, 2010, hlm. 183).

Supaya lebih jelas, persentase antara siswa yang sudah mampuh dan belum mampuh menulis wawangsalan menggunakan model Brain Writing digambarkan seperti di bawah ini.

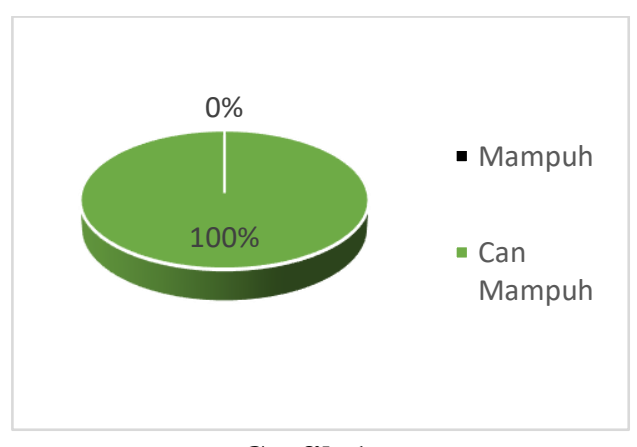

Grafik 1

Kemampuan Menulis Wawangsalan Sebelum Menggunakan Model Brain Writing

Berdasarkan grafik di atas, terlihat bahwa siswa $100 \%$ belum mampu menulis wawangsalan, ini sesuai dengan $\mathrm{KKM}$, siswa yang nilainya $>65$ dianggap mampu menulis wawangsalan, sedangkan $<65$ dianggap belum mampu menulis wawangsalan. Dari hasil sebelum menggunakan model brain writing semua 
siswa belum mencapai KKM. Berdasarkan kemampuan menulis wawangsalan siswa kelas VIII-G SMP Pasundan 4 Bandung dalam aspek ejaan termasuk dalam kategori "kurang", hasil rata-ratanya 2,1 dari skor maksimal 5. Hal ini dilihat dalam menggunakan huruf kapital serta membedakan huruf vokal é, e dan eu.

Dalam aspek pilihan kata (diksi) termasuk dalam kategori "kurang", hasil rata-rata 2,02 dari skor maksimal 5. Artinya masih ada kata yang kurang sesuai, yang menunjukan bahwa siswa masih belum menguasai terhadap kata.

Dalam aspek guru wilangan(jumlah suku kata)termasuk kategori "kurang", hasil rata-rata 2,3 dari skor maksimal 5. Artinya hasil karangan siswa masih kurang dalam menentukan guru wilangan (jumlah suku kata).

Dalam aspek kerapihan tulisan termasuk kategori "kurang", hasil rataratanya 2,3 dari skor maksimal 5. Artinya kurang rapih, tidak terbaca, banyak coretan, tidak menentu antar makna.

Dalam aspek hubungan isi dan judul wangsal termasuk kriteria "kurang" hasil rata-ratanya 2,1 dari skor maksimal 5 . Artinya dalam menentukan isi dan judul wangsal tidak sesuai, jumlah suku kata kurang.

Supaya lebih jelas, gambaran mengenai kemampuan menulis wawangsalan siswa kelas VIII-G SMP Pasundan 4 Bandung sebelum menggunakan model brain riting, seperti di bawah ini.

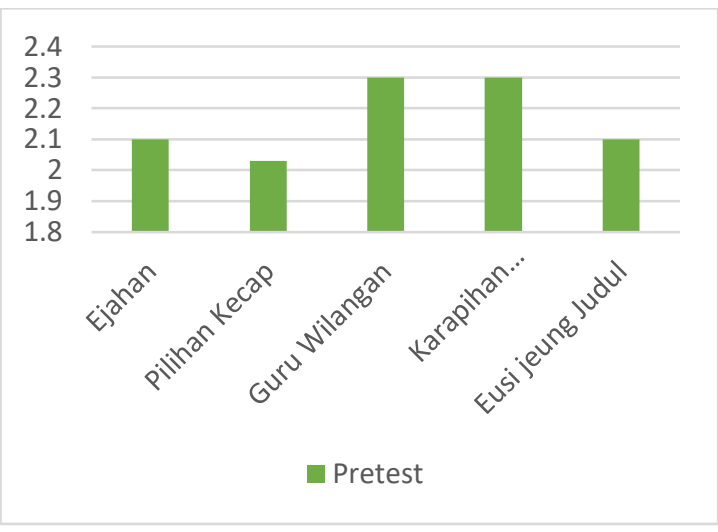

Grafik 2

Rata-rata Kemampuan Siswa dalam Menulis wawangsalan Sebelum Menggunakan Model Brain Writing

Berdasarkan grafik di atas, dari setiap aspek menulis wawangsalan sebelum menggunakan model Brain Writing, yang mempunyai rata-rata paling tinggi yaitu dalam aspek guru wilangan dan kerapihan tulisan yaitu 2,3, sedangkan rata-rata yang paling rendah yaitu dalam aspek pilihan kata dengan rata-rata 2,03.

\section{Kemampuan Menulis Wawangsalan sesudah Menggunakan Model Brain Writing}

Kemampuan menulis wawangsalan sesudah menggunakan model brain writing dari hasil posttest, siswa yang termasuk kategori mampu ada 27 siswa, sedangkan 3 siswa termasuk kategori belum mampu.

Dari hasil kemampuan siswa dalam posttest sudah termasuk kategori mampu, artinya siswa sudah mampu dalam mencapai skor maksimal yang sudah ditentukan aspek-aspek nilai dalm menulis wawangsalan.

Kemampuan menulis wawangsalan sesudah menggunakan model brain writing dianggap mampu.Hal ini sesuai dengan KKM yang sudah ditentukan yaitu $<65$ artinya belum mampuh dalam menulis 
wawangsalan, sedangkan siswa yang nilainya $>65$ artinya mampu dalam menulis wawangsalan.

Supaya lebih jelas, digambarkan grafik seperti di bawah ini.

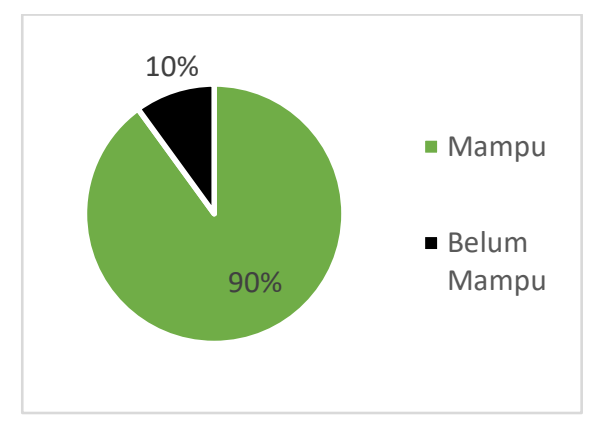

Grafik 3

Kemampuan Menulis Wawangsalan Sesudah Menggunakan Model Brain Writing

Berdasarkan grafik di atas, terlihat bahwa siswa yang mampu dalam menulis wawangsalan yaitu 90\%, sedangkan yang belum mampu $10 \%$.

Berdasarkan menulis wawangsalan siswa kelas VIII-G SMP Pasundan 4 Bandung tahun ajaran 2018/2019, dalam aspek ejaan sesudah menggunakan model brain writingtermasuk baik, rata-ratanya 3,8 dari skor maksimal 5. Artinya dalam menentukan isi dan judul wangsal tidak sesuai, jumlah suku kata kurang.

Dalam aspek pilihan kata sesudah menggunakan model brain writing termasuk baik, rata-ratanya 3,7. Artinya diksi sudah baik, sudah bisa melarapkan diksi yang sesuai, dan murwakanti, sesuai dengan judul wangsal, tetapi masih ada beberapa kesalahan.

Dalam aspek guru wilangan sesudah menggunakan model brain writing termasuk baik, rata-ratanya 3,8. Artinya guru wilangan sudah sesuai, tetapi belum bisa memilih kata yang sesuai.
Dalam aspek kerapihan tulisan sesudah menggunakan model brain writing termasuk baik, rata-ratanya 3,8. Artinya rapih, terbaca, ada sedikit coretan, ejaan masih kurang tetapi tidak merubah makna.

Dalam aspek hubungan isi dan judul wangsal sesudah menggunakan model brain writing termasuk baik, rata-ratanya 3,9. Artinya isi larik dan judul wangsal sudah sesuai, urutannya sudah baik, jumlah susku kata sudah sesuai tetapi ejaan kurang.

Supaya lebih jelas digambarkan grafik seperti di bawah ini.

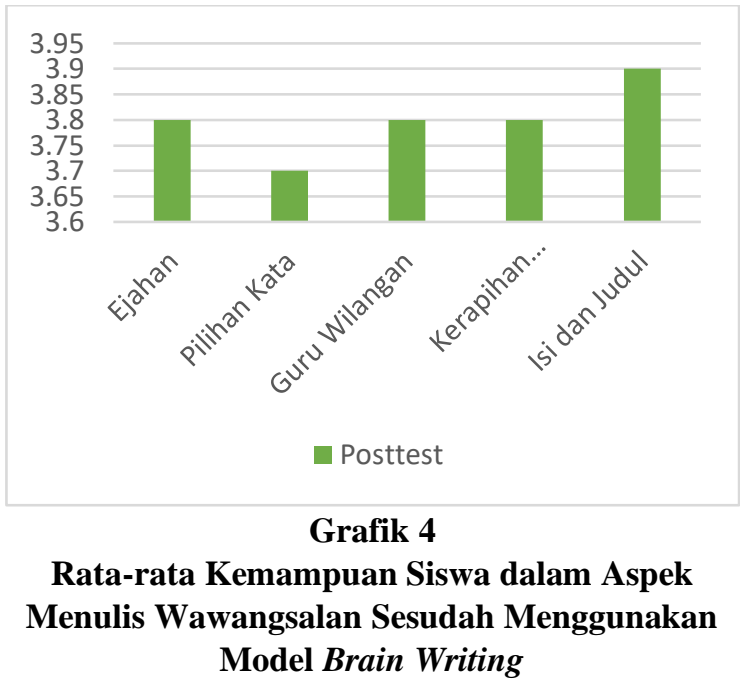

Langkah-langkah

ketika berlangsungnya model pembelajaran dalam menulis wawangsalan, yaitu: 1) siswa dibagi jadi tujuh kelompok, yang masingmasing anggotanya empat siswa, 2) siswa diberi contoh wawangsalan supaya dibaca, dan materi wawangsalan yaitu ejaan, struktur, dan guru wilangan (jumlah suku kata), 3) masing-masing kelompok diberi kertas kosong yang wangsalnya beda-beda, yaitu: kelompok satu japati, kelompok dua tipung, kelompok tiga oli, kelompok empat sate, kelompok lima paying, kelompok enam gelas, kelompok tujuh kutu, 4) 
masing-masing siswa menulis wawangsalan sesuai dengan wangsal yang diterima dalam kelompok, 5) siswa menukarkan karangan wawangsalan ke empat anggota sampai karangan tersebut kembali kepada yang punyanya, 6) siswa yang sudah menerima karangan wawangsalan mengidentifikasi struktur, ejaan, guru wilangan (jumlah suku kata), karangan wawangsalan yang ada dalam kertas tersebut, 7) siswa bisa membenarkan atau mengkoreksi struktur, ejaan, dan guru wilangan (jumlah suku kata) yang ada dalam karangan wawangsalan teman sekelompoknya, 8) sesudah mengidentifikasi struktur, ejaan, dan guru wilangan (jumlah suku kata) dari teman sekelompoknya, siswa menyempurnakan karangan wawangsalan yang diputar tadi, 9) siswa mengedit hasil karangan wawangsalan, 10) siswa mengumpulkan karangan wawangsalan, 11) guru memeberi nilai pada karangan wawangsalan tersebut.

Dalam melakukan langkah-langkah model pembelajaran brain writing siswa sudah mampu dalam menulis wawangsalan. Terlihat bahwa model pembelajaran brain writing bisa meningkatkan kemampuan menulis wawangsalan siswa kelas VIII-G SMP Pasundan 4 Bandung Tahun Ajaran 2018/2019.

Di bawah ini, dibahas ada peningkatan kemampuan menulis wawangsalan sesudah menggunakan model brain writing.

\section{Peningkatan Kemampuan Menulis Wawangsalan sesudah Menggunakan Model Brain Writing}

Berdasarkan hasil pretest dan posttest, kemampuan menulis wawangsalan siswa kelas VIII-G SMP Pasundan 4 Bandung tahun ajaran 2018/2019 sesudah menggunakan model brain writing yaitu meningkat.

Supaya lebih jelas, akan digambarkan grafik seperti di bawah ini.

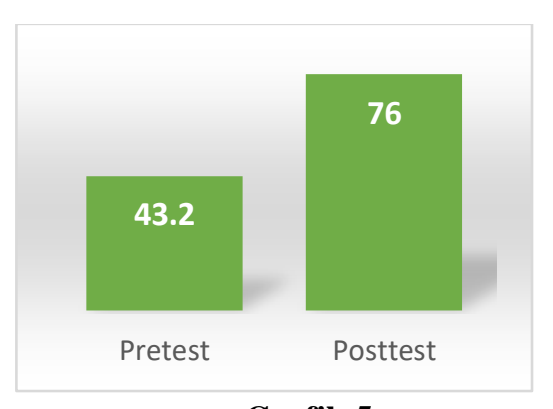

Grafik 5

Rata-rata Kemampuan Menulis Wawangsalan Sebelum dan Sesudah Menggunakan Model Brain Writing

Seperti grafik di atas, bisa terlihat bahwa kemampuan menulis wawangsalan, sesudah menggunakan model Brain Writing meningkat dengan rata-rata 43,2 menjadi 76. Kemampuan Menulis wawangsalan dilihat dari beberapa aspek yaitu rjahan, pilihan kata, guru wilangan, kerapihan tulisan, serta hubungan isi dan judul wangsal.

Dalam aspek ejaan sesudah menggunakan model brain writing termasuk kurang menjadi baik. Rata-ratanya 2,1 menjadi 3,8. Artinya menguasai terhadap kaidah kebahasaan, mampu membedakan é, e, dan eu, huruf kapital diawal kalimat, dan tanda baca.

Dalam aspek pilihan kata sesudah menggunakan model brain writing termasuk kurang menjadi baik. Rata-ratanya 2,03 menjadi 3,7. Artinya diksi sudah sesuai, sudah bisa menerapkan diksi yang sesuai dan murwakanti, sesuai dengan judul wangsal, tapi ada beberapa kesalahan.

Dalam aspek guru wilangan sesudah menggunakan model brain writing termasuk kurang menjadi baik. Rata-ratanya 
2,3 menjadi 3,8. Artinya guru wilangan sudah sesuai, tapi belum bisa memilih kata yang sesuai.

Dalam aspek kerapihan tulisan sesudah menggunakan model wrain writing termasuk kategori kurang menjadi baik. Rata-ratanya 2,3 menjadi 3,8. Artinya rapih, terbaca, ada beberapa coretan, ejaan masih kurang tapi tidak merobah makna.

Dalam aspek hubungan isi dan judul wangsal sesudah menggunakan model brain writing termasuk kurang menjadi baik. Rata-ratanya 2,1 menjadi 3,9. Artinya isi padalisan dan judul wangsal sudah sesuai, urutannya sudah baik, jumlah suku kata sudah sesuai tapi ejaan kurang.

Supaya lebih jelas digambarkan grafik sperti di bawah ini.

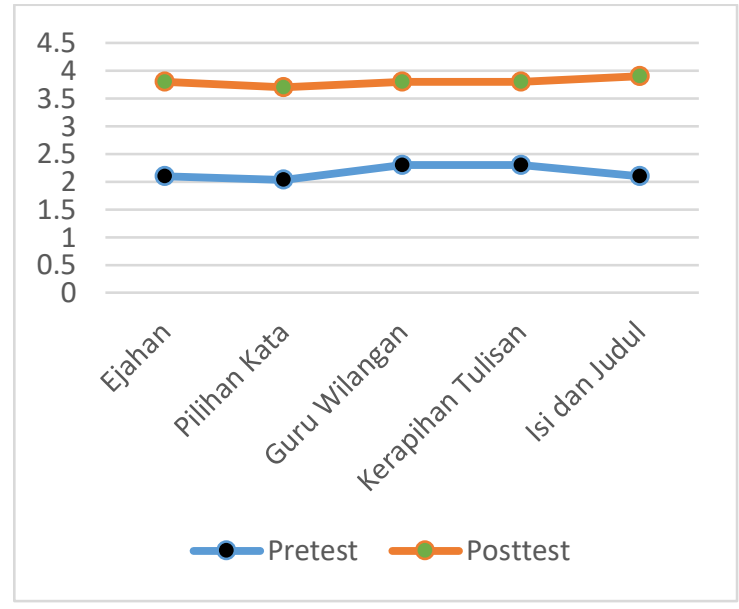

Grafik 6

Rata-rata Kemampuan Siswa dalam setiap Aspek Menulis Wawangsalan Sebelum dan Sesudah Menggunakan Model Brain Writing

Berdasarkan pada grafik di atas, bisa disimpulkan bahwa siswa termasuk kategori belum mampu menjadi mampu dalam aspek ejaan, pilihan kata, guru wilangan, serta hubungan isi dan judul wangsal. Dari semua hasil pretest dan posttest dari 30 siswa aspek yang paling meningkat yaitu aspek hubungan isi dan judul wangsal dengan ratarata 2,1 menjadi 3,9 dari skor maksimal 5 .

\section{Perbedaan antara Kemampuan Menulis Wawangsalan sebelum dan sesudah menggunakan Model Brain Writing}

Untuk mengetahui ada perbedaan antara kemampuan menulis wawangsalan siswa kelas VIII-G SMP Pasundan 4 Bandung, sebelum dan sesudah menggunakan model brain writing, perlu dilakukan uji sipat data, yang terdiri atas uji normalitas dan uji hipotesis.

Uji sipat data dilakukan untuk mengetahui meningkat atau tidaknya kemampuan menulis siswa dalam menulis wawangsalan.

Data kuantitatif dalam penelitian ini dianalisis dengan menggunakan software SPSS PASW versi 18.

Uji normalitas dilakukan untuk mengetahui normal atau tidaknya sumber data yang digunakan. Uji normalitas data kemampuan menulis wawangsalan siswa kelas VIII-G SMP Pasundan 4 Bandung tahun ajaran 2018/2019 sesudah menggunakan model brain writing, hasilnya yaitu:

Tabel 1

Uji normalitas data kemampuan menulis wawangsalan sesudah menggunakan model Brain Writing

One-Sample Kolmogorov-Smirnov Test

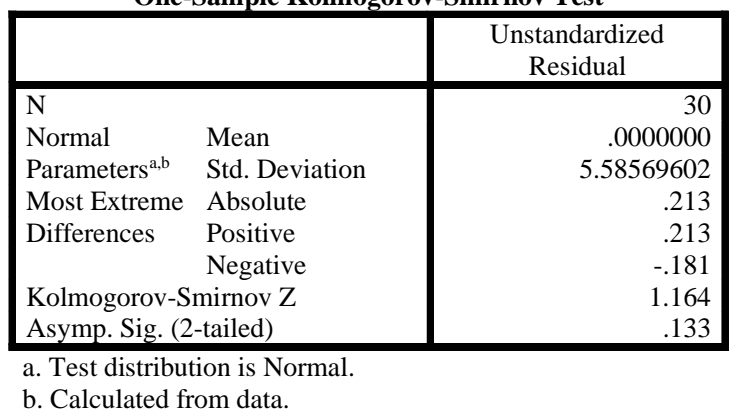


Berdasarkan tabel 1 di atas, terlihat bahwa nilai signifikansi yaitu 0,133 atau lebih dari 0,05. Artinya data normal. Bisa disimpilkan bahwa kemampuan menulis wawangsalan sesudah menggunakan model brain writing termasuk kategori normal.

Uji hipotesis dilaksanakan untuk mengetahui hipotesis kerja $\left(\mathrm{H}_{1}\right)$ diterima dan hipotesis nol $\left(\mathrm{H}_{0}\right)$ ditolak.Karena distribusinya normal digunakan uji parametric dengan menggunakan t-test. Terlihat hasilmengitung $\mathrm{t}$ statistik menghasilkan nilai 18, 727 dan signifikansi (Sig.2-tailed) 0,000. Karena nilai signifikansi (Sig.2-tailed) yaitu $(0,000<$ $0,05)$ atau kurang dari 0,05. Oleh karena itu, $\mathrm{H}_{1}$ diterima serta $\mathrm{H}_{0}$ ditolak. Ada perbedaan yang signifikan antara kemampuan menulis wawangsalan sebelum dan sesudah menggunakan model brain writing.

Dari hasil analisis data yang sudah dibahas, model brain writing bisa meningkatkan kemampuan menulis wawangsalan siswa kelas VIII-G SMP Pasundan 4 Bandung tahun ajaran 2018/2019.

Dari hasil sebelum menggunakan model brain writing, terlihat masih banyak siswa yang belum mampu dalam menulis wawangsalan.Tapi, sesudah menggunakan model brain writing banyak siswa yang sudah mampu.Hasil analisis kemampuan menulis wawangsalan sebelum dan sesudah menggunakan model brain writing siswa kelas VIII-G SMP Pasundan 4 Bandung tahun ajaran 2018/2019 menjadi meningkat. Artinya, model brain writing bisa digunakan dalam menulis wawangsalan.

\section{SIMPULAN}

Berdasarkan penelitian yang sudah dilakukan mengenai model brain writing untuk meningkatkan kemampuan menulis wawangsalan, bisa disimpulkan bahwa kemampuan menulis wawangsalan siswa kelas VIII-G SMP Pasundan 4 Bandung sebelum menggunakan model brain writing termasuk kategori belum mampu. Dari 30 siswa, semuanya nilainya di bawah KKM dengan rata-rata 34,2 ( < 65). Artinya siswa kelas VIII-G SMP Pasundan 4 Bandung tahun ajaran 2018/2019 belum mampu menulis wawangsalan.

Kemampuan menulis wawangsalan sesudah menggunakan model brain writing termasuk kategori sudah mampu. Dari 30 siswa, siswa yang termasuk kategori mampu ada 27 siswa, dengan rata-rata 76. Artinya siswa kelas VIII-G SMP Pasundan 4 Bandung tahun ajaran 2018/2019 sudah mampu menulis wawangsalan.

Peningkatan kemampuan menulis wawangsalan sesudah diterapkan model brain writing termasuk kategori meningkat, dari kurang menjadi baik. Terlihat dari ratarata nilai sebelumnya 34,2 menjadi 76 dari KKM 65. Artinya siswa termasuk kategori dari belum mampu menjadi mampu dalam semua aspek, yaitu aspek ejaan, pilihan kata atau diksi, guru wilangan (jumlah suku kata tiap baris), kerapihan tulisan dan hubungan isi dan judul wangsal. Aspek yang paling meningkat adalah aspek hubungan isi dan judul wangsal dengan rata-rata dari 2,1 meningkat menjadi 3,9.

Ada perbedaan yang signifikan antara kemampua menulis wawangsalan sebelum dan sesudah menggunakan model brain writing siswa. Terlihat berdasarkan hasil pretest kemampuan menulis wawangsalan siswa termasuk kategori belum mampu dengan rata-rata $(43,2)$, sedangkan hasil analisis posttest kemampuan menulis wawangsalan siswa termasuk kategori 
mampu dengan rata-rata (76). Berdasarkan hasil uji statistik nilai signifikansi (Sig. 2tailed) yaitu $(0,000<0,05)$ atau kurang dari 0,05. Oleh karena iu, $\mathrm{H}_{1}$ diterima serta $\mathrm{H}_{0}$ ditolak.

Dengan begitu bisa disimpulkan bahwa ada perbedaan yang signifikan antara kemampuan menulis wawangsalan siswa kelas VIII-G SMP Pasundan 4 Bandung tahun ajaran 2018/2019 sebelum dan sesudah menggunakan model brain writing.

\section{UCAPAN TERIMAKASIH}

Penulis mengucapkan puji dan syukur ke khadirat Allah SWT, dan terima kasih kepada Ibu dan Bapa, serta kepada pihak yang telah mendukung penyelesaian tulisan ini. Semoga tulisan ini bermanfaat untuk pembaca.

\section{CATATAN PENULIS}

Penulis menyatakan bahwa tidak ada konflik kepentingan terkait publikasi artikel ini. Penulis mengkonfirmasi bahwa data dan artikel ini bebas plagiarisme.

\section{PUSTAKA RUJUKAN}

Aljatila. (2015). Meningkatkan Keterampilan Menulis Karangan Deskriptif melalui Model Kooperatif Tipe Round Table pada Siswa Kelas X-I SMAN Kalisusu Barat. Humanika, 3(15). Retrieved from

https://www.google.com/url/sa=t $\&$ source $=$ web \&rct=j\&url=http://oi s.uho.ac.id/index.php/HUMANIK A/article/

Arikunto, S. (2013). Prosedur Penelitian: Suatu Pendekatan Praktik. Jakarta: : Rineka Cipta.

Azizah, T. (2015). Keefektifan Teknik Brain Writing dalam Pembelajaran Memproduksi Teks
Eksplanasi pada Siswa Kelas VII SMP Negeri 1 Sewon Bantul DIY. Universitas Negeri Yogyakarta.

Dinas Pendidikan Jawa Barat. (2013). Kurikulum Tingkat Daerah Muatan Lokal. Bandung: Dinas Pendidikan Jawa Barat.

Kuswari, U. (2010). Evaluasi Pembelajaran Bahasa. Bandung: Jurusan Pendidikan Bahasa Daerah UPI.

Michalko, M. (2004). Permainan Berpikir (Thinkertyos): Handbook Para Pembisnis Kreatif. Bandung: Kaifa.

Mustaqim. (2017). Psikologi Pendidikan. Yogyakarta: Fakultas Tarbiyah IAIN Walisongo Semarang bekerja sama dengan Pustaka Pelajar.

Nasution. (2017). Penggunaan Metode Pembelajaran dalam Meningkatkan Hasil Belajar Siswa. Ilmiah Bidang Pendidikan, 11(1). Retrieved from https://www.google.com/url/sa=t \&source=web\&rct=j\&url=http://ju rnal.uinbanten.ac.id/index.php

Nazir. (2014). Metode Penelitian. Bogor: Ghalia Indonesia.

Nurmayani, R. (2015). Keefektifan Strategi Brain Writing dalam Pembelajaran Menulis Cerpen pada Siswa Kelas X SMA Negeri 1 Ngaglik. Universitas Negeri Yogyakarta.

Suherman, A. (2019). Literacy Tradition of Sundanese Society - Indonesia: An annotation of the 16th Century Ancient

Manuscript. International Journal for Innovation Education and Research, 7(3), 262-271. https://doi.org/10.31686/ijier.Vol 7.Iss3.1377

Sugiyono. (2012). Metode Penelitian Pendidikan Pendekatan 
Kuantitatif, Kualitatif dan $R \& D$. Bandung: Alfabeta.

Sujarweni. (2007). Statistik untuk

Penelitian. Yogyakarta: Graha Ilmu.
Windyagiri. D. (2011). Wawangsalan jeung Sisindiran Anyar. Bandung: Kiblat Buku Utama. 